\title{
AN INVESTIGATION INTO INTERCULTURAL COMPONENTS IN THREE PILOTED ENGLISH TEXTBOOKS FOR VIETNAMESE HIGH SCHOOLS UNDER THE NATIONAL FOREIGN LANGUAGES PROJECT
}

\author{
Kieu Thị Ha* \\ Faculty of Foreign Language and Vietnamese, Infantry Officer Training College Number 1 \\ Co Dong, Son Tay, Hanoi, Vietnam \\ Received 22 April 2020 \\ Revised 22 July 2020; Accepted 20 January 2021
}

\begin{abstract}
Textbooks, as the main source of teaching material, provide learners with not only language input and practice but also intercultural knowledge and skills to build up learners' intercultural communication competence (ICC). This study aimed at finding out whether the English textbooks under the National Foreign Languages Project (commonly known as Project 2020, or NFL) implemented in high schools include intercultural elements and help students in improving students' ICC. The framework by Chao (2011) was used to analyze and categorize the content of the textbooks into different cultural categories. The results of the study indicate that textbook compilers integrated cultural information from various sources including intercultural interactions in the textbook series.
\end{abstract}

Key words: intercultural communication competence, textbooks, cultural categories, Project 2020

\section{Introduction}

In today's world, globalization has brought nations, cultures, and people closer. English becomes the language for international trade, commerce, and communication and its teaching and learning become growing needs (Farzaneh, Konhandami, \& Nejadannsari, 2014). Language does not exist in a vacuum but it is a part of society and culture. Therefore, teaching and learning a language also means learning about the culture of that language. The relationship between language and culture in English language classrooms has been the focus of many studies (Kramsch,1993; Byram,1989).

Communication among people from different cultural backgrounds may cause misunderstanding in intercultural situations as people may base on their cultures for interpretations (Kramsch, 1993). Therefore, there is a hidden risk of false impression and conflict if one uses a language without the understanding of cultural background (Woflson, 1989). To avoid misinterpretation in international situations, learners of foreign

\footnotetext{
* Tel.: 0839192793

Email: kieuha0110@gmail.com
}

languages should draw attention to cultural differences when communicating. Apart from that, they should be equipped with knowledge and skills to deal with conveying their messages in an intercultural environment while learning foreign languages.

Teaching materials have a powerful influence on the process of teaching and learning a language. According to Tomlinson (1998), materials can be instructional, experiential, elicititative, and exploratory for learners to discover the language. Textbooks are one of the main sources of inputs for learners and the language practice that takes place in classrooms. Since the contents of textbooks have a significant association with the learning of the students, it is supposed that textbooks should include intercultural knowledge which can help learners communicate successfully in intercultural contexts. In other words, apart from language skills, textbooks also provide intercultural knowledge and provide chances for learners to improve intercultural communication skills so that they can build up their intercultural communication competence.

In Vietnam, a new English textbook series has been implemented in some Vietnamese 
high schools under the National Foreign Languages Project for 5 years. The new English textbook series shows their improvements in many aspects as compared with the previous ones such as book structure, unit structure, component heading, and time allocated. Since the English textbook series was piloted in high schools, there exists a question about whether the textbooks can serve the objectives of teaching and learning English in the school context. There are some studies to investigate some aspects when implementing the series in some schools. Hoang (2017) looked into teachers' and students' attitudes toward the piloted textbook in a high school in Nam Dinh. In 2018, Nguyen dug into how source culture, target culture, and international culture were represented in the textbook series for high schools in visual forms, texts or listening, and speaking tasks. There has also been much research related to analyzing cultural and intercultural elements and components in textbooks. For example, Farzaneh et al. (2014) sought social-cultural contexts in Top Notch series. However, there has not been any study on intercultural components and learning tasks in the piloted English textbooks under the Project. The above-mentioned reasons motivated me to investigate intercultural components presented in the new pilot textbooks implemented at high schools to find out whether those textbooks could foster intercultural communication in students.

In order to seek the answer to whether English textbooks under the Project launched by the Ministry of Education and Training foster ICC, the study sets out to investigate intercultural components presented in the textbooks. With a view to enhancing students' ICC, it is important that textbooks should provide inputs for students to develop all dimensions of ICC knowledge, attitudes, and skills. The research sought the answer to find out what proportions of intercultural components can be found in the analyzed textbooks. The results of the study can be a reference for teachers for appropriate adaptation and adjustment of the material to suit their teaching contexts as well as to meet their students' needs.

The ten-year English Textbook Series for Vietnamese Secondary Schools under the National Foreign Languages Project 2020 consists of primary textbooks, lower secondary textbooks, upper secondary ones. As a series, there is complete integration and articulation among the textbooks for three levels. Therefore, it is far better to investigate the entire textbook series from grade 3 to grade 12 so that a general overview of intercultural content and learning tasks can be evaluated. Nevertheless, this research study only Student's books for high school level for reasons of space and time.

Particularly, the study only focused on exploiting intercultural elements in relation to other sources of cultural information presented in students' books for grades 10,11, 12 in all forms of information such as reading texts, listening recordings, conversations, learning tasks, pictures.

\section{Literature review}

\subsection{Role of textbooks as a source of cultural inputs}

Textbooks, among the essential components in language classrooms, serve as basic input of the language learners receive and the language practice that occurs in classrooms. They may provide the basis for the content of the lessons and for students, textbooks are major sources of contact that they have with the target language apart from teachers. For language teachers, textbooks serve as a guide which supplies systematic and comprehensive cultural perspectives. With the shift in linguistic theories, people have tended to focus on teaching language in contexts. Social contexts, everyday life, and the natural environment of the target culture have been gradually paid attention to in the textbooks as linguistic inputs. Therefore, foreign language classes should include cultural components incorporated within classroom materials or real-life experiences.

To be effective in promoting intercultural communication competence, it is suggested that textbooks be designed accordingly in a way that both linguistic and cultural objectives should be incorporated. Students should be equipped with the knowledge of not only their own culture but also the target culture as well as other countries' cultures. Apart from that, the intercultural approach in foreign language teaching promotes linguistic competence as well as intercultural communicative competence and aims at developing the awareness of the cultural differences, which may interfere with 
communication and understanding between the learners' own culture and the target culture (Byram, 1997). Nowadays, it is assumed that the knowledge of one's own and foreign cultures broadens one's worldview and in general and enriches one's life by providing access to new cultures.

Language expresses the thoughts, beliefs, and assumptions of a community hence language reflects the way of looking at the world and understanding reality. Byram (1989) believed that language is a tool to express the speaker's knowledge and perception of the real world, thus it reflects their cultural concepts and values. He continued that one cannot learn a language and neglect its culture because speaking a language means expressing its culture, exchanging a language embodies a particular way of thinking and living. Moreover, according to Byram (1989) cultural awareness is very important in language teaching because it contributes to language proficiency. He insisted that any language curriculum should include either implicitly or explicitly elements of its culture because language reflects the speaker's values and perception of the world. Therefore, textbooks, as considered a curriculum guideline, are effective instruments for educational practice, language resources, and sets of cultural values.

In 1997, Byram pointed out three dimensions of intercultural competence knowledge, skills, and attitudes. Having an intercultural attitude means being curious and open towards foreign cultures and being able to understand that one's own attitudes are not the only possible way to perceive the world and reality. Secondly, having intercultural knowledge includes not only knowing about how social groups and identities of foreign culture function and one's own culture function but also understanding the norms and values in every culture. Thirdly, there are intercultural skills that should be taught to learners that are comparing, interpreting, and relating their own culture as well as the foreign cultures. Therefore, it is necessary to include these aspects in textbooks to provide students with models and inputs to practice the language in social contexts. Apart from that, textbooks are also a guideline to teach language learners to search for information on their own since teachers cannot anticipate all the knowledge that they might need in the future.

In language classrooms under the intercultural perspective, students are encouraged to learn languages for cultural understanding to be able to cognitively analyze foreign cultures, people, and cultural artifacts. Integrating linguistic and cultural learning enables the critical assessment of the mainstream culture into which the pupils are socialized. According to Elomaa (2009), textbooks have a critical role in promoting the principles of intercultural learning and teaching as they have a significant influence on pupils' attitudes towards foreign cultures. Ideally, the textbooks would get students interested in the target culture by presenting the culture, language, and mentality of the target countries in an interesting and motivating way. Additionally, the textbook contents should also be meaningful in order to support the intercultural approach. For example, learners should be able to use the learned information in real life. The aim of the intercultural approach is that students would realize that there are no better or worse cultures but just culture-specific features, which direct the use of language and behaviors. Therefore, the teaching of one's own culture and comparing it with other foreign cultures are also a very important aspect of intercultural learning.

\subsection{Cultural and intercultural components in textbooks.}

Textbooks are regarded as important inputs to create cultural contact for learners (Ihm, 1996). Textbooks can vary in terms of the amount and nature of the culture they are conveyed. From an ICC perspective, cultural values must be integrated into textbooks along with the linguistic form. Many models for determining cultural contents in English textbooks have been offered.

Regarding sources of culture, Cortazzi and Jin (1999) propose three types of sources in which culture can be investigated. From their perfectives, cultural content can come from either source culture - learns' native culture or target culture which refers to countries where English is used as the first language, or international culture referring to different varieties of Non-English speaking countries. In 
2011, Chao added two more to the list to form a five-category framework to sort cultural contents in the textbooks which are Intercultural interaction and Universality across culture.

When it comes to cultural dimensions,
Moran and $\mathrm{Lu}$ (2001) introduce five dimensions of culture in which products, practices, perspectives, persons, and communities interact with each other. A brief summary of Moran and Lu's dimensions of culture is presented in Table 1.

Table 1

The Summary of Five Dimensions of Culture (Moran \& Lu, 2001, as cited in Kim \& Paek, 2015)

\begin{tabular}{|c|c|}
\hline Dimensions & Examples \\
\hline \multirow{4}{*}{ Products } & Artifacts: food, documents, language, money, tools \\
\hline & Places: buildings, cities, houses \\
\hline & Institutions: family, law, economy, religion, education, politics \\
\hline & Art forms: music, clothes, dancing, painting, movie, architecture \\
\hline \multirow{4}{*}{ Practices } & Operations: manipulation of cultural products \\
\hline & Acts: ritualized communicative practices \\
\hline & Scenarios: extended communicative practices \\
\hline & Lives: stories of members of the future \\
\hline Perspectives & $\begin{array}{l}\text { They represent the perceptions, beliefs, values and attitudes that underlie the } \\
\text { products and guide people's behavior in the practice of culture. They can be } \\
\text { explicit but often they are implicit, outside conscious awareness. }\end{array}$ \\
\hline Communities & $\begin{array}{l}\text { They include the specific social contexts (e.g. national cultures), circumstances } \\
\text { (e.g. religious ceremonies), and groups (e.g. different social clubs) in which } \\
\text { members carry out cultural practices. }\end{array}$ \\
\hline Persons & $\begin{array}{l}\text { They refer to individual members who embody the culture and its communities in } \\
\text { unique ways. Personal identity and life history play key roles in the development } \\
\text { of a cultural person. }\end{array}$ \\
\hline
\end{tabular}

In this study, the data which reflect at least one aspect of culture according to Moran's model would be collected as cultural elements and classified into different sources of cultures. Intercultural components would be referred to as knowledge about practices and products of cultures such as customs, beliefs, values, taboos, skills to communicate effectively in different social settings, attitudes, and awareness towards similarities and differences among cultures.

\subsection{Sources of cultural information}

The basis for classifying cultural information presented in a textbook is based on Cortazzi and Jin's work. They distinguish cultural information used in foreign language textbooks into three types.

Firstly, source culture materials are understood as the learner's own culture. In the case of Vietnam, this involves using materials based on Vietnamese society and Vietnamese culture, thus it gets learners familiar with the content in textbooks. The main purpose of this category of textbooks is to enable learners to talk about their own country to people from different countries. Secondly, target culture information includes the culture of countries where English is spoken as the first language such as countries in the inner circles of Kachru's circles of English. These textbooks of this category provide learners with cultural information about English speaking countries. Integrating target cultural data into textbooks is supposed to enhance learners' motivation and develop their attitude toward language learning (McKay, 2002).

International cultural information relates to cultures that do not belong to source culture nor target culture. It refers to the culture of countries where English is used as a foreign or international language. In other words, it refers to the cultures of the countries in the outer circle in Kachru's model. English is frequently used in international situations.

Apart from the three categories of cultural information proposed by Cortazzi and Jin, some other types can be found in foreign language textbooks. McKay (2004) reveals that using international target culture content in English as an international language classroom brings benefits to some extents. According to her research, learning cultural information from international cultures allows learners to expose to a variety of cultures and develop crosscultural sociolinguistic competence. They have more chances to build up their own ideas about how to communicate appropriately with English 
speakers in international contexts. Additionally, more exposure to international culture materials will support learners in internalizing the cultural norms of non-native speaker's cultures rather than native English speakers when communicating and exchanging information, which will result in the development of ICC. Therefore, English textbooks should supply learners with a plethora of opportunities to effectively enhance their ICC through the contents and learning tasks.

Based on categories of culture by Cortazzi and Jin (1999) and McKay (2004), Chao (2011) employs more domains which are intercultural interaction and universality cross-culture. The framework, which was designed to assist university English learners to have comparisons or reflections on the differences or similarities between their local and target/international cultures, was coded under Intercultural Interaction (ICI). Generally, the content, which is mainly in correlation to linguistic knowledge and practice without focusing on any particular culture or country, was coded under Universality across Culture (UC). Compared to the previous frameworks, Chao's covers more aspects of culture contents presented in textbooks in general. It draws people to the aspect of communication between different cultures, differences and similarities as well as focus on the matter of intercultural communication and intercultural communication competence when classifying cultural contents Besides, this research also has the same context in which the framework was developed. English in Vietnam plays the role of a foreign language, it is one of the media of communicating with people from different countries. Therefore, in the context of this research, I adapted Chao's (2011) to categorize cultural contents in textbooks. However, when applying to English textbooks in Vietnam, some changes should be made to suit the context of the research. SC refers to Vietnamese culture.

Table 2

The Categories and the Criteria to Classify Culture (adapted Chao, 2011)

\begin{tabular}{|c|c|}
\hline Cultural categories & Explanations \\
\hline source culture (SC) & It refers to Vietnamese culture. \\
\hline target culture (TC) & $\begin{array}{l}\text { It includes English-speaking countries in the inner circle (Australia, Canada, Ireland, } \\
\text { New Zealand, the UK and the USA). }\end{array}$ \\
\hline $\begin{array}{l}\text { international culture } \\
\text { (InC) }\end{array}$ & $\begin{array}{l}\text { It includes cultures of all countries in the world (European countries, countries in } \\
\text { Latin America, Africa, and Asia) except for Vietnamese and English-speaking } \\
\text { cultures. }\end{array}$ \\
\hline $\begin{array}{l}\text { intercultural interaction } \\
\text { (ICI) }\end{array}$ & $\begin{array}{l}\text { It includes the comparison, reflection, intercultural communication, or awareness } \\
\text { of the differences and similarities between the local/source and the } \\
\text { target/international culture through activities such as case studies, problem- } \\
\text { solving, and role-play to help students develop positive attitudes, knowledge, } \\
\text { skills, and awareness in international communication. }\end{array}$ \\
\hline $\begin{array}{l}\text { universality across culture } \\
\text { (UC) }\end{array}$ & $\begin{array}{l}\text { It includes general knowledge/content that is not specific to any particular culture } \\
\text { or country. }\end{array}$ \\
\hline
\end{tabular}

\section{Methodology}

\subsection{Textbook description}

Data consisted of three textbooks series for three grades and each textbook series has two volumes which are entitled Tiếng Anh 10, Tiếng Anh 11, and Tiếng Anh 12, published by Vietnam Education Publishing House. These books are the results of the collaboration of Vietnam Education Publishing House and Pearson Education. It is expected that after finishing high school, students will achieve CEFR level B1. Compared to the previous textbook series, English textbooks under the Project are developed from a multi-component approach taking topics as the starting point. The development of four macro-skills, linguistic elements (pronunciation, vocabulary, and grammar) and intercultural aspects are regarded as the means to be taught so that together these components will contribute to the development of the school student's comprehensive communicative competence (Hoang, 2016).

In the textbook series under the Project, high school textbooks vary from lower secondary and primary textbooks in terms of textbook structure, the number of units, the unit structure, the number of components of each unit, and how a unit begins and ends (Hoang, 2015).

The textbook series for high school students consists of student's books, teacher's books, 
and workbooks and CDs. In terms of textbook structure, each textbook for high school students is organized around 10 units and 4 reviews which are separated into two volumes for each semester of a school year.

Each book provides a book map which presents the topics of each unit, language functions and notions, phonological and lexical items related to the topic, and grammatical structures realizing the functions and notions, and cross-cultural contents for the textbook of each grade (Hoang, 2016). There is a consistent structure for each unit and each review. Each unit is presented in 10 pages. Topic, language focus, reading, speaking, listening, writing, communication \& culture and project are incorporated across eight-lesson titles. Each of the titles consists of varying exercises and communicative tasks or activities which require individual work, pair work, group work, class discussion, and different patterns of interaction among teacher and students.

In each textbook volume, there are two reviews: one after the third unit, and the other after the fifth unit. In this section, students have a chance to revisit grammar points, lexical items, and phonological patterns from the previous units as well as four language skills focusing on topics in previous units.

A consistent structure is applied for all units in the English textbooks for three grades. Each unit includes eight sections which are equivalent to eight periods/ lessons. In terms of components, each unit in textbooks for high school students consists of eight headings: Getting Started, Language, Reading, Speaking, Writing, Communication \& Culture, and Looking back \& Project.

Each heading contributes to develop students' communicative language areas as well as improve the level of proficiency. Getting started aims at introducing the topic of the unit, eliciting student's existing knowledge of the topic. In Language period, students are provided with grammar points, lexical items related to the topic. Apart from supplying knowledge, four skill-based lessons create a learning environment for students to develop communicative language use. In Communication \& Culture, students learn to use English in social-cultural contexts and read about an aspect of a specific culture. In the last lesson of each unit, students revise language patterns and produce real work about the topic they have learned.

A unit of grade 10 through to grade 12 begins with a dialogue about the topic of which incorporates phonological and lexical items related to the main topic, grammar points, and specific functions and notions. These language elements and language functions are enhanced, practiced, expanded, and integrated into four following lessons which aim at developing four macro skills: reading, speaking, listening, writing and some cultural contents related to the topic. The unit ends with a project which provides students with opportunities to use the language learned throughout seven lessons to perform communicative tasks in real contexts.

\subsection{Research instruments}

In order to answer the research question, the qualitative method and quantitative method were applied. Content analysis is a research technique that provides new insights, increases the researcher's understanding of particular phenomena, and informs practice. Therefore, a content analysis of textbooks for high school students was conducted to determine intercultural elements in textbooks. The culturerelated contents in these textbooks, exercises, and the learning tasks are used as the baseline data for content analysis.

When it comes to the proportion of intercultural contents in the textbook series. The textbook culture-related contents were coded according to the adaptation of Chao's (2011) categories of sources of culture. Under this scheme, cultural information was divided into five groups: source culture, target culture, international culture, intercultural interaction, and universality across culture as presented in Table 2 SC refers to Vietnamese culture. TC includes English-speaking cultures such as England, America, Australia, New Zealand, and so on. InC represents the cultures of all countries other than SC and TC. On the other hand, ICI includes content that reflects the similarities and differences in cultures among the 'SC', 'TC', and 'IC. Culture-neutral or culture-free contents were counted as Universality across culture.

A coding scheme was developed to analyze data and categorize data according to the existing framework based on Chao's (2011) categories of culture. 
The source culture: native cultural representations of learners. In this situation, the source culture is Vietnamese cultural representations, which can be found in three textbook series.

The target culture: culture representations of the cultures where English is the first language, for example, the United States, the UK, Canada, Australia, and New Zealand.

The international culture: cultural representations of non-Vietnamese culture and non-English speaking countries in Africa, Asia, or Europe.

The intercultural interaction: there is a comparison, reflection, intercultural communication or awareness of the differences and similarities between the local/source and the target/international culture.

Universality across culture: it includes general knowledge or general contents, which do not belong to any specific culture.

When all texts, listening transcripts, and visuals were investigated and classified into each category, a quantitative tool was conducted to calculate the proportion of Intercultural elements in three textbooks and its correlation with other sources of cultural information.

\subsection{Data collecting procedure}

In every heading, visual elements and written forms were analyzed separately. Pictures, maps, charts, graphs, signs, photographs, and illustrations were classified into visual elements. Written forms such as names of characters, places, themes of written texts, or any culture references were put into one group. General contents such as culturefree statements or scientific facts that did not belong to any specific cultures and could not determine their specific source of culture were grouped as Universality across culture.

In order to classify cultural elements into different categories, names of countries appearing in each analysis unit were highlighted and coded into different categories such as Target culture, Source culture, International culture, or Intercultural interaction. For those elements that could not be determined any cultural references would be put into Universality across culture. The analysis units of the study included reading passages, notes, text, listening transcript and pictures, and all other activities in the student's books.

The frequency of each cultural element in each section of each unit was counted and recorded in a coding table.

\subsection{Data analysis}

To answer the first research question, after making the data units selected and excluded in phase one, the main ideas of the texts, recording, activities, exercises, and visual elements were scrutinized and coded them with categories and types of culture using framework as presented in the previous section. The collected data was recorded in the content analysis table that enabled to count the frequency of cultural sources. In order to determine the cultural categories, the name of countries mentioned in each text and visuals was noted and put into different sources of cultural information. Then the main ideas of each reading, pictures, and other visuals were determined and coded according to guidelines to identify intercultural components.

The first domain of the textbook analysis was source culture. Most examples of Vietnamese culture were contextualized in Vietnam in modes of social addressing system. All over the textbook series, the use of given names instead of surnames was found. In almost all situations of all units, characters use first names in communicating with others such as "Mai, Nam, Quan, Hieu, Phong, Anna, Scott...". Besides, Vietnamese culture was also presented in the textbooks through different features as Geography, Architecture, Economics, Historical features...; for instance, a brief biography of Van Cao, a reading text about Ha Long Bay, or a listening recording about Phong Nha Ke Bang. Apart from that, Vietnamese "values" cultural elements, through the introduction of health beliefs such as "Ailments are caused by an imbalance of yin and yang" found in Tieng Anh 10. Additionally, a few Vietnamese festivals were described in the textbooks such as "Elephant racing festival", "Forest worshipping festival" in Tieng Anh 12. A number of introductions of musical works or art forms were also illustrated source culture such as "Tien quan ca", "Noi vong tay lon", or "Quan Ho" singing. 
Regarding target culture, there were a lot of written texts which describe features of culture in countries in the Inner Circle. In some cases, the target culture was described separately. In particular, most instances of target culture were contextualized in England, Britain, The USA, the UK, and Australia. An introduction of the British educational system, curriculum, subject descriptions, and discussing the education structure, institutions, and organizations in Tieng Anh 11 was an example. Besides, some customs and superstitions in target culture were introduced such as some superstitions in Britain in Tieng Anh 10. In addition to the names of the countries, the names of the cities and places such as London, New York, California, three textbooks also referred to American and British values were also presented through the standard of education with the names and description of degrees, certificates, and level such as ASLevel, TOK, IB, A-level (Tieng Anh 11, p. 22)

The third domain was international culture. In three textbooks international culture can be found in several written texts. Most examples of international cultural references belonged to Asian culture. The names of countries and regions were found in great density such as Asian, Korea, Indonesia, Malaysia, Thailand, Laos, China, Japan. Apart from that, many cultural elements belonging to other countries and regions such as India, German, Sweden, Europe, Costa Rica, Africa were also named in the textbooks. Moreover, the textbook set also referred to geographic locations of places that characters come from. Names and descriptions of international organizations such as UNESCO, UNICEF, East Meets West contribute to the completion of the picture of International culture represented in the textbooks.

Concerning the fourth domain intercultural interactions, in the textbooks, Vietnamese culture content was primarily compared and contrasted to target culture and international culture in numerous aspects and cases. From those written texts, similarities and differences between those cultures in several aspects and the interactions between those cultures could be found, for instance, the comparison on the ideas of success between American and Vietnamese people. The intercultural interactions were mostly in forms of communication among people from different cultures such as John and Van talking about a historical figure, Nguyen Trai, in Tieng Anh 12. Another example could be found in Tieng
Anh 10, in Unit 2, there was a conversation between Nam and Scott talking about the saying "An apple a day keeps doctors away". The names of the characters gave a clue that they were from different cultural backgrounds, and their exchanges in the conversation were based on their understanding and more or less embodied their cultures.

Additionally, written forms without any cultural references or with general knowledge or general facts would be grouped into universality across culture.

Regarding visuals, there were a large number of visuals in the textbook series. Images in the textbooks series are mostly the prompts to elicit students' background knowledge about the topic or illustrations for the content. There are pictures, maps, or charts with brief descriptions including cultural references to trace back the sources of culture. Images referring to Vietnamese culture could be easily identified. In Unit 3, Tieng Anh 10, there were pictures of Quan ho singing, Van Cao, Vietnamese television programs which illustrated the content of the listening recording, a biography, or pictures for discussion. In addition to that, when introducing historical places in Vietnam, images of Flag Tower of Hanoi, the Centre Sector of the Imperial Citadel of Thang Long, Hoi An ancient town, Hue Imperial Citadel, and so on were included in different parts to depict the content of the texts or the recordings.

Concerning target culture, pictures of famous people, places and destinations, charts showing trends could be found in the textbook set. For example, before listening to a conversation about their favorite songs in Unit 3, Tieng Anh 10, the textbook provided students with pictures of famous musicians such as Michael Jackson, Elton John. Another example can be found in Tieng Anh 12, pictures of Steve Jobs, Larry Steward, Conan Doyle were presented when introducing topics "Life stories".

Regarding images depicting the international culture, a large number of pictures of Asian countries, cities, flags as well as attractive destinations in those countries were illustrated. In addition, $\operatorname{logos}$ or symbols of international organizations were also found such as World Wide Fund for Nature (WWF) or Association of Southeast Asian Nations (ASEAN).

Additionally, the textbooks also presented a small number of visuals showing the 
interactions among people from different countries. In those images, people from different countries communicated with each other such as pictures of foreign students wearing Ao dai and interacting with Vietnamese people in Unit 7, Tieng Anh 11.

In terms of universality across culture, a large number of illustrations could be found in three textbooks. They were cartoon pictures or images with no specific cultural references. These visuals were grouped into the fifth category as cultural neutral elements.

The results of the procedures were presented in the content analysis table. Then the frequency of each source of culture was calculated and the proportion of intercultural components was figured out to see its correlation with other sources of culture.

To make the results more objective and more reliable, I conducted an independent analysis with another B.A holder. The results then were correlated for further analysis.

\section{Findings}

The textbook series contains 30 units and 12 reviews and each unit contains eight headings. In total, I examine 252 headings to collect data about sources of cultural information. All paragraphs, reading texts, listening scripts, and notes were counted as relevant texts. Conversations and dialogues were counted as texts. Those texts may provide cultural contexts through which factual information can be introduced comprehensively and accurately. Besides, all pictures, maps, charts, graphs in three textbooks were included for analysis as those visual elements also contain cultural information and they also reflect human life. Therefore, they are a useful source of cultural inputs.

In detail, I examined 264 texts and 789 visuals (see in Table 3). If one unit presents cultural content, it was analyzed and placed under a suitable category.

Table 3

Number of Aspects of Analysis on Cultural-Related Content

\begin{tabular}{lcccc}
\hline \multicolumn{1}{c}{ Book } & $\begin{array}{c}\text { Tieng Anh } \\
\mathbf{1 0}\end{array}$ & $\begin{array}{c}\text { Tieng Anh } \\
\mathbf{1 1}\end{array}$ & $\begin{array}{c}\text { Tieng Anh } \\
\mathbf{1 2}\end{array}$ & Total \\
\hline $\begin{array}{l}\text { visuals (pictures, maps, charts, graphs...) } \\
\begin{array}{l}\text { texts (paragraphs, reading texts, dialogues, passages, } \\
\text { conversations, notes, .... }\end{array}\end{array}$ & 82 & 89 & 93 & 264 \\
\hline $\begin{array}{l}\text { Throughout the three textbooks, cultural } \\
\text { content was almost evenly presented both } \\
\text { tangibly and intangibly. After examining 264 }\end{array}$ & $\begin{array}{l}\text { suitable categories, the proportion } \\
\text { intercultural components was calculated and } \\
\text { presented in Table 4. }\end{array}$ & 287 & 789 \\
\end{tabular}
texts and 789 pictures and placing them under

Table 4

Percentage of Source Culture, Target Culture, International Culture, Intercultural Interaction and Universality Across Culture in Three Textbooks

\begin{tabular}{|c|c|c|c|}
\hline \multirow{2}{*}{ Culture categories } & \multicolumn{2}{|c|}{ Aspects of analysis } & \multirow{2}{*}{ Sum } \\
\hline & Texts & Visuals & \\
\hline source culture & 85 & 128 & $\begin{array}{c}213 \\
(20.2 \%)\end{array}$ \\
\hline target culture & 36 & 40 & $\begin{array}{c}76 \\
(7.2 \%)\end{array}$ \\
\hline international culture & 42 & 87 & $\begin{array}{c}129 \\
(12.3 \%)\end{array}$ \\
\hline intercultural interaction & 28 & 11 & $\begin{array}{c}39 \\
(3.7 \%)\end{array}$ \\
\hline universality across culture & 73 & 524 & $\begin{array}{c}597 \\
(56.7 \%)\end{array}$ \\
\hline
\end{tabular}


Table 4 presents the percentage and frequency of four types of culture in the textbooks series. It can be found that throughout the three textbooks, Universality across culture accounted for more than half of analysis units with 56.7 percent. Source culture was given the second most concern with 20.2 percent. Ranking the third is International culture with 12.3 percent, which was not so far surpassed Target culture in the amount with 7.2 percent. Accounting for the most modest proportion among four categories is Intercultural interaction with only 3.7 percent. In three textbooks series, it can be seen that the proportion of Universality across culture is the largest.

There are a lot of analyzed units in textbooks which have no cultural reference such as a picture of two people talking to each other, a picture of a part of a city, a group discussion, or a reading text about conflicts in a family with no cultural references, a conversation about using robots. Visuals and written texts have no direct references to any cultures, some referring to general categories such as teachers, doctors, global warming. In these cases, English is used as a medium to convey information and exchange information.

It is not difficult to see that the textbooks tried to include all sources of cultural information. Cultural-related contents come from five sources. Among those sources, the mild bias in favor of Universality across culture, Source culture, and International culture, Target culture proving that textbook writers tried to serve the purpose of multicultural content. The intercultural interaction only accounted for a rather modest proportion.

\section{Table 5}

Frequency of Source Culture, Target Culture, International Culture, Intercultural Interaction and Universality across culture

\begin{tabular}{llccc}
\hline Culture categories & Aspects of analysis & Tieng Anh 10 & Tieng Anh 11 & Tieng Anh 12 \\
\hline & texts & 30 & 29 & 26 \\
Source culture & & $36.6 \%$ & $32.6 \%$ & $28 \%$ \\
& visuals & 45 & 49 & 34 \\
& & $19 \%$ & $17.1 \%$ & $12.8 \%$ \\
Target culture & texts & 14 & 8 & 14 \\
& & $17.1 \%$ & $9 \%$ & $15.1 \%$ \\
& visuals & 22 & 2 & 16 \\
International culture & texts & $9.3 \%$ & $0.7 \%$ & $6 \%$ \\
& & 9 & 20 & 13 \\
& visuals & $11 \%$ & $22.5 \%$ & $14 \%$ \\
Intercultural interaction & texts & 12 & 53 & 22 \\
& & $5.1 \%$ & $18.5 \%$ & $8.3 \%$ \\
& visuals & 9 & 9 & 10 \\
& & $11 \%$ & $10.1 \%$ & $10.8 \%$ \\
Universality across culture & texts & 0 & 7 & 4 \\
& & $0 \%$ & $2.5 \%$ & $1.1 \%$ \\
& visuals & 20 & 23 & 30 \\
& & $24.4 \%$ & $25.8 \%$ & $32.2 \%$ \\
& & 158 & 176 & 190 \\
& & $66.7 \%$ & $61.3 \%$ & $71.7 \%$ \\
\hline
\end{tabular}

Table 5 shows the comparison of cultural categories among the three books in different cultural aspects. In terms of visual, Universality across culture elements occupy the largest proportion with $66.7 \%, 61.3 \%$, and $71.7 \%$ in the same order of Tieng Anh 10, Tieng Anh 11 and Tieng Anh 12. Regarding Vietnamese cultural elements, Tieng Anh 10, Tieng Anh 11 seemed to have no considerable difference in amount with $19 \%$ and $17.1 \%$; however, Vietnamese cultural elements compose $12 \%$ in Tieng Anh 12. For visual target culture content, Tieng Anh 10, Tieng Anh 12 were more densely represented with $9.3 \%$ and $6 \%$ in comparison with those in Tieng Anh 11 with only $0.7 \%$. Pictures of International culture were more densely represented in Tieng Anh 11 with 18.5\% rather than those in Tieng Anh 10 and 
Tieng Anh 12 with 5.1\% and $8.3 \%$ respectively. In contrast, there was a small proportion of pictures of Intercultural interaction presented in Tieng Anh 11 and Tieng Anh 12, which were $2.5 \%$ and $1.1 \%$, and visual intercultural interaction could not be found in Tieng Anh 10. In regards to all written forms of texts in the textbooks, written texts about universality across culture content a bit surpassed in Tieng Anh 12 with $32.3 \%$ rather than those in Tieng Anh 10, 11 which are 24.4 and 25.8 percent. In addition, there was almost no significant difference in written Vietnamese culture content in three textbooks with the amount of $36.6 \%, 32.6 \%$, and $28 \%$ respectively. Texts of the target culture in Tieng Anh 10 and Tieng Anh 12 were roughly the same, which were $17.1 \%$ and $15.1 \%$ while in Tieng Anh 11 they accounted for only $9 \%$. In contrast to the trend in texts of target culture, the proportion of written forms of international culture in Tieng Anh 11 surpassed the amount with 22\% meanwhile, they constitute only $11 \%$ in Tieng Anh 10 and 14\% in Tieng Anh 12. In terms of written forms of intercultural interaction, there was almost no significant difference bias toward any textbooks. They were represented with roughly the same amount in three textbooks which were $11 \%, 10.1 \%$ and $10.8 \%$ in the same order.

One of the purposes of the study is to investigate intercultural components presented in the textbooks for high schools under the Project. In the textbooks, the distribution of intercultural pictures was unequal but there was a balanced number of intercultural pictures among three textbooks. The visuals that carry messages or represent the interactions among people from different countries can mostly be found in Tieng Anh 11.

From the textbook analysis process, it can be seen that textbook writers tried to construct various situations in which Vietnamese people communicate and interact with foreigners on certain topics like education, music, values, social norms and many others. For example, in Tieng Anh 11, there is a conversation among three people, Phong, Kevin, and Marian. They are talking about "Further education" and how they understand the term "Further education". Based on the name of the characters, three speakers are from different countries with different presuppositions about the topic. Nevertheless, what they exchange for one another is quite common knowledge about the higher education system.

Additionally, intercultural elements were also found in written texts comparing cultural customs, values, or superstitions in different countries. In Tieng Anh 11, a comparison of raising children in the US and Vietnam was presented in Unit 3. The text showed the differences in the mindset. While American parents often help their children become selfreliant, Vietnamese parents tend to overprotect their kids. Another example was illustrated in Tieng Anh 10, Unit 7. The text as an input for speaking tasks presented the differences in traditions and customs in Russia and the UK. This text provided students with knowledge of social life in two countries such as popular drinks, sports, and beliefs. In the same unit, the text supplied information about the similarities and differences in the ideas of success in Vietnam and America. The textbooks presented not only comparisons in traditions or customs but also the social aspects. In Tieng Anh 12, in a writing task, there was a line graph comparing the urbanization rates in Korea and Indonesia Unit 3.

Although textbook writers included written texts and pictures carrying intercultural components, the result of the textbook analysis indicated that the intercultural interaction materials were seriously under-represented in all of the English textbooks. The percentage of ICI in three textbooks was just 3.7 percent. The result showed that English textbooks tended to pay less attention to intercultural issues, though they were considered an essential part of developing learners' ICC.

Through the process of analyzing cultural elements especially, intercultural elements, it can be concluded that the analyzed textbooks included knowledge of cultures, which are the inputs for the practices integrated into the learning tasks in the textbooks. The textbooks, to a certain extent, help to enhance students' knowledge of different cultures, which is also a significant aspect of developing students' ICC.

\section{Conclusion}

Teaching materials have a powerful influence on the process of teaching and learning a language. Textbooks are not only one of the main sources of language input and practice but also a supply of intercultural 
knowledge and skills to build up learners' intercultural communication competence. To communicate successfully in an intercultural environment, students should be drawn their attention to the issue and equipped with sufficient skills. For those reasons, it drove me to conduct this study to find out whether current textbooks implemented in the school can help teachers and students in improving students' intercultural communication competence. Besides, there can be suitable adaptation and adjustment of materials to serve students' demands and the requirements to help students to be confident and successful in communication in international contexts.

The study was conducted with two main phases: data collection and data analysis. Before conducting phase one, I reviewed the framework to categorize sources of cultural information in the textbook by Chao (2011) and adapted it to make it more appropriate with the context of the study. After that, a coding scheme was developed to collect relevant data for analysis. Based on the guidelines from the framework by Chao (2011), visual information and written texts were investigated and put into different categories.

As relevant data was collected, I built up the content analysis table to describe and analyze the data, one was to report data about the sources of cultural information. The results of the study indicate that textbook compilers integrate cultural information from various sources including intercultural interactions in which people from different cultures communicate with one another or different aspects of different cultures are put together to find out similarities and differences or people from one culture interact with the environment of other countries. The textbook series provides intercultural knowledge as well as other cultural materials for students to practice in classrooms. It is also consistent with the guiding principles of developing the textbook series stated in Hoang (2015). In his article, he pointed out one of the basic principles for developing textbooks was to ensure that cross-cultural issues are adequately incorporated into the contents of the textbooks. As Byram (1997) and Scollon \& Scollon (1995) mentioned, intercultural communicative competences can be enhanced when students are exposed to a culturally rich environment in which they internalize the norms of different cultures. In this regard, Byram et al state that "materials from different origins with different perspectives should be used together to enable learners to compare and to analyze the materials critically. It is more important than learners acquire skills of analysis than factual information" (1994, p. 19). This means that the representation of ICI in current English textbooks should be modified or improved in a way that helps students to develop their ICC.

From the results of the data analysis processes, it can be noticed that the proportion of intercultural components and the learning tasks addressing IC in three textbooks series is different. The differences may result from the differences in cultural themes presented in those textbooks and there is properly no standardized figure to the distributions of intercultural elements and tasks in three textbooks.

Hence, it is concluded that the analyzed textbooks series is a good English textbook set from the perspective of ICC. Textbook writers are concerned about developing students' ICC by including cultural and intercultural elements, which are inputs for linguistic as well as cultural practices. To help students enhance ICC comprehensively, the knowledge of cultures is not adequate. By conducting the activities and the learning tasks demonstrated in these textbooks, students have chances to develop their intercultural attitudes and skills. It also follows the recent trend in English textbooks writing for learners who take English as a foreign language. Current English textbooks tend to be designed to improve intercultural dynamics by incorporating more topics on ICI into culture-related content and IC learning tasks.

Teaching and learning English cannot be separated from teaching and learning its culture. To support students master English effectively via textbooks, cultural elements should be highlighted during the lessons. The teachers also need to draw students' attention to the issue of intercultural communication and help them to be aware of cultural differences in international environments to conduct activities presented in the textbooks.

The results of the research provide teachers who are using the textbook series with another 
perspective about three textbooks. For those teachers who approach the textbook under the perspective of intercultural communication competence, this study can be a reference for them when they use and adapt the textbooks to have appropriate adjustments with different learners.

With the analysis above, teachers' responsibility to find practical solutions to integrate cultural teaching into their language teaching in one way or another. Teachers can plan their own extensive teaching program on cultures, especially for extra-curriculum activities or involve intercultural activities in their four skills lessons.

Nevertheless, unless teachers are interculturally competent and knowledgeable, it is doubtful that they can help foster the interculturality of their students. To do that, there should be plans and policies to draw teachers' attention to this issue and help them enhance their knowledge and skills of teaching.

Besides, every high school also needs to provide teachers with the proximal environment to implement their plan to enhance students' interculturality.

\section{References}

\section{English}

Byram, M. (1989). Cultural studies in foreign language education. Multilingual Matters.

Byram, M. (1997). Teaching and assessing intercultural communication competence. Multilingual Matters.

Byram, M., \& Morgan, C. (1994). Teaching and learning language and culture. Multilingual Matters.

Chao, T. (2011). The hidden curriculum of cultural content in internationally published ELT textbooks: A closer look at new American inside out. The Journal of Asia TEFL, 8(2), 189-210.

Cortazzi, M., \& Jin, L. (1999). Cultural mirrors: Materials and methods in the EFL classroom. In E. Hinkel (Ed.), Culture in second language teaching and learning (pp. 196-219). Cambridge University Press.

Farzaneh, N., Kohandami, M., \& Nejadansari, D. (2014). A textbook evaluation of socio-cultural contexts in top notch series. In K. Sadeghi, S. Modirkhameneh, P. Alavinia \& Z. A. Khonbi (Eds.), Procedia - Social and Behavioral Sciences (Vol. 98, pp. 472-481). Elsevier.
Hoang, V. V. (2015). The development of the ten-year english textbook series for Vietnamese schools under the National Foreign Languages 2020 Project: A cross-cultural collaborative experience. VNU Journal of Science: Foreign Studies, 31(3), 1-17. https://js.vnu.edu.vn/FS/article/view/15

Hoang, V. V. (2016). Renovation in curriculum design and textbook development: An effective solution to improving the quality of english teaching in Vietnamese schools in the context of integration and globalization. VNU Journal of Science: Education Research, 32(4), 9-20. https://doi.org/10.25073/25881159/vnuer.3845

Hoang, T. C. (2017). Teachers' and students' attitudes towards the piloted textbook english 10: The case of Nghia Hung upper secondary school, Nam Dinh city [Master's thesis, Vietnam National University, Hanoi]. VNU Repository. http://repository.vnu.edu.vn/handle/VNU_123/54427

Ihm, H. (1996). A study of the cultural content of illustrations in selected elementary school ELF/ESL textbooks [Doctoral dissertation, the University of Georgia]. ProQuest Dissertations and Theses.

Kim, S. Y., \& Paek, J. (2015). An analysis of culturerelated content in English textbooks. Linguistic Research, 32(1), 83-104.

Kramsch, C. (1993). Context and culture in language teaching. Oxford University Press.

McKay, S. L. (2002). Teaching English as an international language: Rethinking goals and approaches. Oxford University Press.

McKay, S. L. (2004). Teaching English as an international language: The role of culture in Asian contexts. The Journal of ASIA TEFL., 1(1), 1-22.

Moran, P. R., \& Lu, Z. (2001). Teaching culture: Perspectives in practice. Heinle \& Heinle.

Nguyen, T. H. H (2018). A study on the Features of Source culture, Target culture and International culture Represented in textbook Tiếng Anh 10, Tiêng Anh 11 and Tiếng Anh 12 of the 10-Year Curriculum [Master's thesis, Vietnam National University, Hanoi]. VNU Repository. http://repository.vnu.edu.vn/handle/VNU_123/65103

Scollon, R., \& Scollon, S. W. (1995). Intercultural Communication: A Discourse Approach. Basil Blackwell.

Tomlinson, B. (1998). Materials development in language teaching. Cambridge University Press.

Woflson, N. (1989). Perspectives: Sociolinguistics and TESOL. Newbury House Publishers.

\section{Finnish}

Elomaa, E. (2009). Oppikirja eläköön! Teoreettisia ja käytännön näkökohtia kielten oppimateriaalien uudistamiseen. [Doctoral dissertation, University of Jyväskylä]. https://jyx.jyu.fi/bitstream/handle/123456789/41080/978951-39-5141-2_2009.pdf?isAllowed=y\&sequence $=1$ 


\title{
TÌM HIỂU CÁC YẾU TỐ LIÊN VĂN HÓA TRONG SÁCH GIÁO KHOA TIẾNG ANH THÍ ĐIỂM CẤP TRUNG HỌC PHỔ THÔNG THUỘC ĐỀ ÁN NGOẠI NGỮ QUỐC GIA
}

\author{
Kiều Thị Hà \\ Khoa Ngoại ngũu - Tiếng Việt, Trường Sĩ quan Lục quân 1 \\ Cổ Đông, Son Tây, Hà Nội
}

Tóm tắt: Sách giáo khoa được coi là nguồn tài liệu giảng dạy chính; chúng cung cấp cho người học không chỉ kiến thức ngôn ngữ mà còn kiến thức và kỹ năng liên văn hóa giúp bồi dưỡng và phát triển kỹ năng giao tiếp liên văn hóa. Nghiên cứu này tìm hiểm xem liệu rằng bộ sách giáo khoa Tiếng Anh trong khuôn khổ Đề án Ngoại ngữ Quốc gia được thí điểm ở cấp trung học phổ thông có bao gồm các yếu tố liên văn hóa và giúp học sinh phát triển năng lực giao tiếp liên văn hóa hay không. Nghiên cứu này sử dụng khung lý thuyết của Chao (2011) để phân tích và phân loại các yếu tố văn học theo nguồn gốc. Kết quả nghiên cứu chỉ ra rằng bộ sách có chứa đựng những yếu tố văn hóa từ các nguồn khác nhau và bao gồm cả các yếu tố liên văn hóa.

Từ khóa: năng lực giao tiếp liên văn hóa, sách giáo khoa, các loại văn hóa, Đề án Ngoại ngữ Quốc gia 